\title{
Geloof in eigen kunnen: het effect van JOBS, een groepsinterventie voor werklozen
}

\author{
Veerle Brenninkmeijer, Arjan Van Houwelingen, Roland Blonk en \\ Nico Van Yperen*
}

In dit onderzoek staat de JOBS-training centraal, een groepstraining gericht op de reïntegratie van werklozen (Vinokur, Van Ryn, Gramlich \& Price, 1991) door middel van het verhogen van de zelfeffectiviteit van de deelnemers. Eerst is een theoretische vergelijking gemaakt tussen de vier bronnen van zelfeffectiviteit (Bandura, 1977a) en de componenten van JOBS. Vervolgens is in een longitudinale studie onder 281 JOBS-deelnemers het effect van JOBS op de zelfeffectiviteit getoetst. Deze studie laat zien dat de JOBS-training inderdaad leidt tot een stijging van de zelfeffectiviteit op de korte en lange termijn (na één en zes maanden). De stijging op de korte termijn was sterker aanwezig bij vrouwen. De stijging in zelfeffectiviteit bleek niet samen te hangen met het vinden van werk, maar het absolute niveau van zelfeffectiviteit wel.

Trefwoorden: JOBS-training, zelfeffectiviteit, werkloosheid

\section{Inleiding}

$\mathrm{Na}$ een aantal jaren van economische groei heerst er de afgelopen jaren in Nederland een periode van stijgende werkloosheid. Het percentage werklozen onder de Nederlandse beroepsbevolking is sinds 200 gestegen van 3,5 tot $6,5 \%$ in

* Dr. V. Brenninkmeijer,TNO Kwaliteit van Leven | Arbeid, Hoofddorp. Correspondentieadres: Dr. V. Brenninkmeijer, TNO Kwaliteit van Leven | Arbeid, Team Activering, Postbus 718, 2130 AS Hoofddorp. E-mail: v.brenninkmeijer@arbeid.tno.nl.

Drs. A. Van Houwelingen, Rijksuniversiteit Groningen.

Prof. dr. R.W.B. Blonk, TNO Kwaliteit van Leven | Arbeid, Hoofddorp; Universiteit Utrecht.

Prof. dr. N.W. Van Yperen, Rijksuniversiteit Groningen. 
2004 (CBS, 2005). Het gaat hierbij om mensen van 15-64 jaar zonder werk (of met werk voor minder dan twaalf uur per week), die actief op zoek zijn naar betaald werk en daarvoor beschikbaar zijn.

Werkloos worden is een ingrijpende gebeurtenis. Uit veel onderzoeken is gebleken dat personen die hun baan verliezen een verhoogd risico hebben op problemen met betrekking tot hun mentale gezondheid en sociaal functioneren (zie voor een overzicht McKee-Ryan, Song, Wanberg \& Kinicki, 2005; zie ook Catalano, I99I; Dooley \& Catalano, I980; Kessler, Turner \& House, I988; Vinokur, Caplan \& Williams, 1987). Uit longitudinaal onderzoek is gebleken dat deze negatieve gevolgen van werkloosheid verdwijnen bij werkhervatting (e.g. Caplan, Vinokur, Price \& Van Ryn, I989; Kessler et al., I988; Vinokur et al., I987). Het is dus niet alleen van maatschappelijk belang dat werklozen snel weer werk vinden, maar het is ook belangrijk voor het welzijn van de werklozen zelf.

Voor personen met een ongunstige arbeidsmarktpositie die niet op eigen kracht werk kunnen vinden, is er gerichte ondersteuning bij het zoeken naar werk. Verschillende partijen zijn hiervoor verantwoordelijk en zijn betrokken bij de arbeidstoeleiding van werklozen. Dit betreft bijvoorbeeld het Centrum voor Werk en Inkomen (CWI), de Uitvoeringsinstantie Werknemers Verzekeringen (UWV), gemeenten en reïntegratiebedrijven. Onder arbeidstoeleiding wordt verstaan: het verkleinen van de afstand tot de arbeidsmarkt voor werklozen of het terugbrengen van werklozen op de arbeidsmarkt door middel van allerlei activerings- en stimuleringsmaatregelen. Eén van die maatregelen is het inzetten van interventieprogramma's voor werklozen.

Een interventieprogramma dat zich specifiek richt op werklozen met een ongunstige arbeidsmarktpositie en dat sinds een aantal jaren op de Nederlandse markt bestaat, is het JOBS-programma. Het JOBS-programma is een kortdurende training gericht op de reïntegratie van werklozen. De JOBS-training, kortweg JOBS genoemd, is afkomstig uit Amerika en is in I984 ontwikkeld in het Michigan Prevention Research Center aan de universiteit van Michigan door de onderzoeksgroep van Price en Vinokur (Price, Van Ryn \& Vinokur, 1992). Het JOBS-programma is een groepsprogramma dat aangestuurd wordt door twee begeleiders. De grootte van de groep kan variëren van ro tot 25 mensen, maar een aantal van 15 deelnemers lijkt optimaal bij mensen met een relatief grote afstand tot de arbeidsmarkt. De groep deelnemers doorloopt een programma dat bestaat uit vijf ochtenden van vier uur, gedurende één week. Het is daarmee een kort en intensief programma.

Het programma is strak geprotocolleerd, waarbij elke ochtend een vaste volgorde van oefeningen kent. De oefeningen worden complexer naarmate de week vordert en zijn bedoeld om succesvolle werkzoekvaardigheden aan te leren. De oefeningen hebben betrekking op onderwerpen als: leren denken als een werkgever, informatie inwinnen bij een bedrijf, een sollicitatiegesprek voeren, gebruikmaken van je netwerk en het schrijven van sollicitatiebrieven en cv's. Naast het aanleren van vaardigheden in het zoeken van werk door middel van deze oefeningen zijn er nog een aantal, deels overlappende, componenten waarmee JOBS gekarakteriseerd kan worden. Deze componenten worden later uiteengezet. 


\section{Resultaten JOBS}

Sinds de ontwikkeling van het programma is JOBS veelvuldig onderzocht. Onderzoek laat zien dat deelnemers die JOBS volgen vaker een baan vinden dan mensen in de controleconditie, waarbij deelnemers een folder toegestuurd kregen met daarin tips voor het vinden van een baan (Caplan et al., 1989). De training verlaagt ook de kans op depressieve symptomatologie en vermindert periodes van zware depressie bij deelnemers met depressieve symptomen (Price et al., I992; Caplan, Vinokur, \& Price, 1997). Onderzoek van Van Ryn en Vinokur (1992) laat zien dat ook de zelfeffectiviteit voor wat betreft het zoeken naar werk stijgt en dat deze variabele mogelijk een belangrijk mechanisme is waardoor de JOBS-training succes heeft.

Ook op de lange termijn heeft JOBS effect. Na ruim twee jaar heeft het merendeel van de deelnemers (8I\%) nog steeds baat bij de training. Ten opzichte van de controlegroep hebben meer deelnemers werk, zijn zij minder vaak van werkgever gewisseld en hebben zij een hoger loon (Vinokur, Van Ryn, Gramlich \& Price, I99I). Deze effecten zijn ook in andere landen gevonden (Eden \& Aviram, I993; Vuori, Silvonen, Vinokur \& Price, 2002).

In Nederland is onderzoek naar het JOBS-programma verricht door TNO. Het programma is vertaald en qua stijl, voorbeelden en rollenspelen aangepast aan de Nederlandse cultuur en situatie. Zo is bijvoorbeeld de wijze waarop deelnemers gecomplimenteerd en bedankt worden voor hun inbreng minder nadrukkelijk aanwezig in de Nederlandse versie. Inhoudelijk is het Nederlandse JOBS-protocol echter identiek aan het Amerikaanse protocol. JOBS bleek ook in Nederland effectief (Blonk \& Brenninkmeijer, 2005). Na zes maanden hadden meer JOBS-deelnemers een baan ten opzichte van respondenten in de andere condities (persoonsgebonden reïntegratiebudget en controleconditie). Ook waren deelnemers in de JOBS-conditie meer tevreden met de begeleiding en tendeerden zij naar een sterkere stijging in zelfeffectiviteit voor wat betreft het zoeken van werk

Een belangrijke vraag die uit de onderzoeken van Van Ryn en Vinokur (I992) en Blonk en Brenninkmeijer (2005) naar voren kwam, is in hoeverre de effecten op het vinden van werk toe te schrijven zijn aan een stijging van de zelfeffectiviteit. Met andere woorden, is het versterken van de zelfeffectiviteit één van de werkzame mechanismen van JOBS die de kans op werk vergroten? Dat is de centrale vraagstelling van dit onderzoek. Daarnaast zullen we ook exploratief onderzoeken of er verschillen zijn tussen demografische groepen voor wat betreft de verandering in zelfeffectiviteit. Alvorens in te gaan op bovenstaande vragen, zullen we ons eerst richten op de vraag wat zelfeffectiviteit precies is en op welke manieren een gevoel van zelfeffectiviteit kan ontstaan. Vervolgens bespreken we op welke wijze de JOBS-training aangrijpt op deze bronnen van zelfeffectiviteit.

\section{Zelfeffectiviteit: definitie en bronnen}

Bandura (1997) definieert waargenomen zelfeffectiviteit in zijn boek Self-Efficacy: the Exercise of Control als volgt: 'Perceived self-efficacy refers to beliefs in one's capabilities to organize and execute the courses of action required to produce given 
attainments'. Waargenomen zelfeffectiviteit kan derhalve beschouwd worden als een subjectief oordeel over de eigen vaardigheden of competentie om een bepaalde prestatie neer te zetten. Zelfeffectiviteit heeft diverse gevolgen voor mensen: het beïnvloedt de keuze voor het ondernemen van acties; de hoeveelheid inspanning die wordt geleverd om een bepaald doel te behalen; het doorzettingsvermogen bij obstakels en falen; en het prestatieniveau dat uiteindelijk wordt behaald (zie voor een overzicht Bandura, I997).

Waargenomen zelfeffectiviteit wordt volgens Bandura (1977a) geconstrueerd en aangepast op basis van vier verschillende informatiebronnen: uitvoerende ervaringen ('performance accomplishments'), indirecte ervaringen ('vicarious experience'), verbale overreding ('verbal persuasion') en de fysiologische en affectieve toestand ('emotional arousal').

Uitvoerende ervaringen hebben een zeer sterke invloed op de waargenomen zelfeffectiviteit. Successen bouwen een robuuste overtuiging van zelfeffectiviteit op. Deze sterke overtuiging van zelfeffectiviteit kan zich ook verspreiden naar andere activiteiten en situaties. Mislukkingen kunnen daarentegen de waargenomen zelfeffectiviteit ondermijnen. Incidentele mislukkingen kunnen de waargenomen zelfeffectiviteit echter juist bevorderen als zij, door inzet, kunnen worden omgezet in succeservaringen. Hierdoor kan men het gevoel krijgen dat men, bij aanhoudende inspanning, zelfs de moeilijkste obstakels aan zou kunnen. Enige moeilijkheden en tegenslagen bij bezigheden leert ons derhalve dat slagen het gevolg is van aanhoudende inspanning.

Niet alleen eigen ervaringen maar ook indirecte ervaringen kunnen invloed hebben op de mate van zelfeffectiviteit. Het zien van succesvolle ervaringen van anderen ('modeling') is een tweede manier waardoor een gevoel van persoonlijke effectiviteit kan worden beïnvloed. Het kan hierbij gaan om personen die men 'in levende lijve' ziet, maar ook om beschrijvingen of bijvoorbeeld videofragmenten van personen. Uit succeservaringen van anderen kan men de hoop putten dat men zelf ook succesvol kan zijn, of zichzelf kan verbeteren, als men zich voldoende inspant. Voorbeelden van anderen die effectieve copingstrategieën laten zien, kunnen de zelfeffectiviteit derhalve vergroten, ook bij personen met een lage waargenomen zelfeffectiviteit. Bandura geeft hierbij wel aan dat indirecte ervaringen afhankelijk zijn van sociale vergelijkingsprocessen en hierdoor minder robuuste informatie leveren dan eigen (succes)ervaringen.

Verbale overreding is een derde manier waarop een gevoel van zelfeffectiviteit bevorderd kan worden. Verbale overreding, waarbij wordt gesuggereerd dat men de benodigde capaciteiten heeft om een bepaalde taak te beheersen, wordt weliswaar veel gebruikt, maar het effect op zelfeffectiviteit lijkt enigszins beperkt. In bepaalde omstandigheden kan verbale overreding volgens Bandura de zelfeffectiviteit en inspanning wel stimuleren, bijvoorbeeld als er ook ondersteunende hulpmiddelen worden geboden.

De vierde informatiebron waardoor zelfeffectiviteit wordt geconstrueerd, betreft de fysiologische en affectieve toestand. Tijdens stressvolle of veeleisende bezigheden kunnen mensen een sterke fysiologische activatie ervaren. Deze activatie kunnen ze als angst of gevoeligheid voor stress interpreteren. Omdat een sterke fysiologische activatie veelal belemmerend werkt bij het leveren van prestaties, schatten mensen 
hun zelfeffectiviteit lager in wanneer zij een sterke fysiologische activatie bij henzelf waarnemen. Stressreacties op een dergelijke interpretatie kunnen de fysiologische activatie nog verder versterken, waardoor succesvolle prestaties nog meer belemmerd worden.

Uit het bovenstaande komt naar voren dat er vier manieren zijn waarop de waargenomen zelfeffectiviteit kan stijgen. Hieronder wordt uiteengezet hoe de JOBS-training zich daarop richt.

\subsection{Zelfeffectiviteit en de componenten van JOBS}

De JOBS-training heeft een aantal theoretisch gefundeerde componenten, die elkaar deels overlappen (Price et al., I992; Van Ryn \& Vinokur, I992): vaardigheidstraining ('job-search skill training'), het actieve leerproces ('the learning process'), anticiperen op belemmeringen en teleurstellingen ('inoculation against setbacks') en de sociale steun van trainers en de groep ('social support from trainers and group'). Deze componenten sluiten op verschillende manieren aan op de vier bronnen van zelfeffectiviteit, zoals geformuleerd door Bandura (uitvoerende ervaringen, indirecte ervaring, verbale overreding en fysiologische en affectieve stimuli). De aansluiting met de bronnen van Bandura is echter voor sommige componenten van de JOBStraining duidelijker dan voor andere componenten. In tabel I staat de aansluiting tussen de componenten van JOBS en de bronnen van zelfeffectiviteit schematisch weergegeven.

Tabel 1 Aansluiting componenten JOBS en informatiebronnen zelfeffectiviteit (Bandura)

\begin{tabular}{ll} 
Informatiebron zelfeffectiviteit & Componenten JOBS die zich hierop richten \\
\hline Uitvoerende ervaringen & $\begin{array}{l}\text { Vaardigheidstraining } \\
\text { Actief leerproces (oefeningen) } \\
\text { Indirecte ervaringen }\end{array}$ \\
$\begin{array}{l}\text { Vaardigheidstraining } \\
\text { Actief leerproces (oefeningen, groepsdiscussie) }\end{array}$ \\
$\begin{array}{l}\text { Actief leerproces (groepsdiscussie, impliciete sturing } \\
\text { trainers) } \\
\text { Sociale steun van trainers en de groep }\end{array}$ \\
Fysiologische en affectieve toestand & Anticiperen op belemmeringen en teleurstellingen \\
\hline
\end{tabular}

De vaardigheidstraining is gericht op het verbeteren van de effectiviteit van werkzoekvaardigheden en is mede gebaseerd op de sociale-leertheorie ('social learning theory') van Bandura (1977b, 1986). Deelnemers kunnen niet alleen zelf ervaring opdoen met diverse werkzoekvaardigheden, ze kunnen ook zien hoe andere deelnemers de oefeningen uitvoeren. Deze component grijpt dus aan op de eerste twee bronnen van zelfeffectiviteit: uitvoerende ervaringen en indirecte ervaring.

Het leerproces is actief opgezet. De kennis en ideeën van deelnemers worden ontlokt door kleine en grote groepsdiscussies en andere activiteiten. Zo ligt de nadruk op het boven tafel krijgen van de al aanwezige kennis en ervaring bij de deelnemers in de groep. Deelnemers worden bijvoorbeeld aangemoedigd elkaar concrete tips te geven. Deelnemers besteden daarnaast veel tijd aan het oefenen van vaardigheden. 
De kennis en ervaring van de trainers komt op een meer indirecte manier aan bod. De trainers begeleiden de activiteiten op een impliciete manier, waarbij ze kennis inbrengen en activiteiten sturen door het stellen van vragen, het doorvragen en het samenvatten van antwoorden. Op deze wijze worden deelnemers bewust gemaakt van hun eigen kennis en ervaring.

Het actieve leerproces sluit op verschillende bronnen van Bandura aan. Het oefenen van vaardigheden sluit, zoals hierboven aangegeven, aan op de eerste twee bronnen van zelfeffectiviteit: uitvoerende ervaringen en indirecte ervaring. De aansluiting van de groepsdiscussies op de bronnen van Bandura is echter minder duidelijk. Men zou dit kunnen beschouwen als vormen van indirecte ervaring, waarbij mensen via discussie zien hoe andere mensen werk zoeken en omgaan met obstakels. Aan de andere kant zou men het ook kunnen beschouwen als een vorm van verbale overreding. Deelnemers bemoedigen elkaar in hun vaardigheden/competenties en geven elkaar veel concrete tips. De manier waarop trainers de groepsdiscussies en andere activiteiten leiden, kan worden beschouwd als een vorm van (impliciete) verbale overreding.

Het anticiperen op belemmeringen en teleurstellingen is gebaseerd op het werk van Meichenbaum (1985) en Janis \& Mann (1977). Bij het zoeken naar werk kunnen verschillende tegenslagen of barrières verwacht worden. In de JOBS-training worden mogelijke tegenslagen en barrières geïnventariseerd en worden deelnemers hierop voorbereid. Vaak worden emotionele spanningen ('zenuwen') genoemd door deelnemers als obstakel bij het zoeken en vinden van werk. Vervolgens wordt gekeken hoe men deze spanningen zou kunnen verminderen, vooraf of tijdens bijvoorbeeld een sollicitatiegesprek. De component 'anticiperen op belemmeringen en teleurstellingen' lijkt hiermee enigszins aan te sluiten bij de vierde bron van zelfeffectiviteit: fysiologische en affectieve stimuli.

Sociale steun wordt op verschillende manieren bevorderd. Sociale steun wordt gegenereerd doordat trainers expliciet ondersteunend gedrag vertonen, waaronder uiting van empathie en erkenning voor de zorgen en gevoelens van deelnemers, het geven van positieve feedback en het aanmoedigen van inspanningen van deelnemers. Daarnaast zijn de groepsactiviteiten erop gericht dat deelnemers elkaar kunnen steunen. Dit wordt ook bekrachtigd door de trainers. De component 'sociale steun' sluit aan bij de derde bron van zelfeffectiviteit: verbale overreding. Door middel van het geven van bijvoorbeeld positieve feedback wordt een gevoel van zelfeffectiviteit middels verbale overreding bevorderd.

\subsection{Belang van zelfeffectiviteit voor het vinden van werk}

De centrale vraag in dit onderzoek is of het versterken van de zelfeffectiviteit ertoe leidt dat mensen eerder een baan vinden. Oftewel, is het versterken van de zelfeffectiviteit een van de werkzame mechanismen van JOBS die de kans op werk vergroten? Het belang van zelfeffectiviteit voor het zoeken naar werk en de intentie om te zoeken naar werk is uit eerder onderzoek naar voren gekomen. Onderzoek naar de determinanten van werkzoekgedrag heeft zich gericht op de Theory of Planned Behavior (TPB) van Ajzen (I99I). Onderzoek van Blonk en Versteeg (2002) toont het belang aan van zelfeffectiviteit voor wat betreft werkzoekgedrag (het ondernemen van activiteiten gericht op het vinden van werk) en werkzoekintentie (de intentie 
om activiteiten te ondernemen gericht op het vinden van werk) (Blonk \& Versteeg, 2002, maar zie ook Van Hooft, Born, Taris, Van der Flier \& Blonk, 2004). Ook uit onderzoek naar de effectiviteit van JOBS waarin de TPB centraal stond (Van Ryn \& Vinokur, 1992), kwam naar voren dat zelfeffectiviteit gerelateerd is aan werkzoekgedrag en werkzoekintentie.

Hoewel zelfeffectiviteit samenhangt met werkzoekgedrag en werkzoekintentie, betekent dit niet automatisch dat het versterken van zelfeffectiviteit de kans op het vinden van werk zal vergroten. Het vinden van werk hangt namelijk mede af van macro-economische factoren, zoals bijvoorbeeld het aanbod van banen (Taris, Heesink \& Feij, 1995). Daarnaast spreken onderzoeken elkaar tegen wat betreft de mate waarin het vinden van werk wordt bepaald door werkzoekgedrag (Wanberg, Watt \& Rumsey, 1996). Verondersteld wordt dat met name de kwaliteit van het werkzoekgedrag van belang is voor het vinden van werk, en niet zozeer de intensiteit (Wanberg, Glomb, Song \& Sorenson, 2003). Ook kan verondersteld worden dat mensen, wanneer zij een mogelijke baan in het vooruitzicht hebben, juist minder werkzoekgedrag vertonen. Ze hebben immers al bijna een baan.

In dit onderzoek wordt allereerst bepaald in hoeverre de zelfeffectiviteit van deelnemers stijgt na het volgen van de JOBS-training, zowel op de korte termijn (na één maand) als op de lange termijn (na zes maanden). Voorts zal exploratief onderzocht worden of er verschillen zijn tussen demografische groepen in de mate van zelfeffectiviteit, zowel voor als na de JOBS-training. Daarbij zal worden gekeken naar geslacht, etnische achtergrond, opleidingsniveau, leeftijd en duur van de werkloosheid. Ten slotte wordt onderzocht of een stijging in zelfeffectiviteit al dan niet samenhangt met het vinden van werk.

\section{Methode}

\subsection{Deelnemers en procedure}

De onderzoeksgroep werd geleverd door een gemeente en door twee reïntegratiebedrijven. Voorafgaand aan de JOBS-training kregen de deelnemers uitleg over het onderzoek en werd hun gevraagd of ze mee wilden doen. Na deze uitleg werden toestemmingsformulieren uitgedeeld waarop deelnemers konden aangeven of ze wel of niet wilden deelnemen. Vervolgens kregen de deelnemers die hadden ingestemd met het onderzoek de gelegenheid de eerste vragenlijst in te vullen. De ingevulde vragenlijsten werden naar TNO opgestuurd. De tweede en derde vragenlijst werden met een retourenvelop via de post naar het thuisadres van de respondent gestuurd. Voor elke ingevulde en geretourneerde vragenlijst ontvingen de deelnemers voor de eerste en tweede vragenlijst een Irischeque ter waarde van vijf euro. Voor de laatste (derde) vragenlijst was de beloning een Irischeque van tien euro. De JOBS-training zelf was niet verplicht, maar werd wel standaard ingezet. Als mensen een goede reden hadden om niet aan JOBS deel te nemen (bijvoorbeeld vanwege een sociale fobie), dan werd een uitzondering gemaakt.

Het onderzoek is uitgevoerd met een longitudinaal design bestaande uit drie meetmomenten: vlak voor de training, één maand later en zes maanden later. Voor het 
eerste meetmoment zijn in totaal ongeveer 700 vragenlijsten uitgezet. Hiervan werden 449 (ongeveer 64\%) geretourneerd. Het aantal vragenlijsten op de eerste en tweede nameting bedraagt respectievelijk 369 en 339 . Bij II deelnemers waren alle drie de vragenlijsten zeer inconsistent ingevuld. Deze lijsten zijn daarom niet meegenomen in het onderzoek. Daarnaast gaven 39 respondenten aan al voor de training een baan (voltijd of deeltijd) te hebben. Deze personen zijn geëxcludeerd om het effect van de training zo zuiver mogelijk te kunnen schatten. Van de resterende deelnemers hadden 28I personen alle drie de vragenlijsten ingevuld. Deze deelnemers zijn meegenomen in het uiteindelijke onderzoek.

De kenmerken van de uiteindelijke onderzoeksgroep zijn weergegeven in tabel 2. De groep bestond voor $5 \mathrm{r} \%$ uit vrouwen en $45 \%$ van de deelnemers was 50 jaar of ouder. Van de deelnemers was $77 \%$ autochtoon en $23 \%$ allochtoon. Mensen werden als allochtoon beschouwd wanneer zij zelf of hun ouders buiten Nederland waren geboren. Verder kreeg 46\% van de deelnemers een WW-uitkering, 23\% kreeg een bijstandsuitkering, $9 \%$ procent een $\mathrm{WAO}$-uitkering en $20 \%$ procent een andere type uitkering of een combinatie van uitkeringen. Voor de verdeling met betrekking tot opleiding, werkervaring en de duur van de werkloosheid zie tabel 2.

Tabel 2 Kenmerken van de onderzoeksgroep ( $N=281$, meetmoment 1)

\begin{tabular}{llr} 
Kenmerk & Categorie & Percentage deelnemers \\
\hline Geslacht & Man & $49 \%$ \\
Leeftijd & Vrouw & $51 \%$ \\
& $<30$ jaar & $7 \%$ \\
& 30 t/m 39 jaar & $22 \%$ \\
& 40 t/m 49 jaar & $25 \%$ \\
Hoogste opleiding & 50 jaar en ouder & $45 \%$ \\
& Lager onderwijs & $13 \%$ \\
& mavo/lbo/vbo & $27 \%$ \\
Etnische achtergrond & mbo & $32 \%$ \\
& havo/vwo/hbo/universiteit & $28 \%$ \\
Aantal jaren werkervaring & Nederlands & $77 \%$ \\
& Overig & $23 \%$ \\
& $<1$ jaar & $4 \%$ \\
& 1 tot 5 jaar & $13 \%$ \\
& 5 tot 10 jaar & $17 \%$ \\
& 10 tot 20 jaar & $17 \%$ \\
Duur huidige werkloosheid & 20 jaar en langer & $49 \%$ \\
& $<6$ maanden & $16 \%$ \\
& 6 maanden tot 1 jaar & $18 \%$ \\
& 1 tot 2 jaar & $24 \%$ \\
& 2 tot 5 jaar & $21 \%$ \\
Type uitkering & 5 jaar en langer & $22 \%$ \\
& Bijstand & $23 \%$ \\
& WW & $46 \%$ \\
& WAO & $9 \%$ \\
& Anders of combinatie & $20 \%$ \\
\hline
\end{tabular}




\subsection{Interventie}

De JOBS-training, waaraan alle deelnemers hebben deelgenomen, wordt gegeven in vijf dagdelen op vijf aaneengesloten dagen (zie hierboven voor een beschrijving van de inhoud van de JOBS-training). Na de JOBS-training kregen mensen verschillende vormen van begeleiding. Van de deelnemers heeft $70 \%$ een individueel gesprek gehad met een reïntegratieconsulent. Het gaat hierbij veelal om één tot vier gesprekken. Ook heeft een aantal mensen (Iо\%) een individueel gesprek gehad met iemand van de sociale dienst. Ook hierbij gaat het meestal om één tot vier gesprekken. $2 \mathrm{r} \%$ geeft aan dat zij andere begeleiding hebben gehad na de JOBS-training. Hierbij gaat het vooral om het volgen van een sollicitatietraining.

\subsection{Analyse selectieve uitval}

Om te controleren voor selectieve uitval zijn de deelnemers die alle vragenlijsten hebben ingevuld vergeleken met de uitvallers op de tweede en derde vragenlijst op de variabelen: geslacht, afkomst, hoogst afgeronde opleiding, leeftijd, aantal jaren werkervaring, huidige periode werkloosheid en zelfeffectiviteit op het eerste meetmoment. In de groep die uitviel was de etnische achtergrond van de deelnemers significant vaker niet-Nederlands $(\mathrm{F}(\mathrm{I}, 329)=\mathrm{I} 2.74, \mathrm{p}<$.oI $)$. Verder bleek de leeftijd bij de groep die uitviel significant lager $(\mathrm{F}(\mathrm{I}, 329)=\mathrm{I} 6.9 \mathrm{I}, \mathrm{p}<. . \mathrm{II})$, evenals het totaal aantal jaren werkervaring $(\mathrm{F}(\mathrm{I}, 329)=\mathrm{I} 3.25, \mathrm{p}<$.oI $)$ en de opleiding die men had genoten $(\mathrm{F}(\mathrm{I}, 329)=4.07, \mathrm{p}<.05)$.

\subsection{Meetinstrumenten}

\section{Zelfeffectiviteit}

Zelfeffectiviteit werd gemeten met een schaal van acht items, die is afgeleid van schalen gebruikt door Ellis en Taylor (1983) en Van Ryn en Vinokur (1992). De vragen werden als volgt ingeleid: 'De volgende vragen gaan over uw zelfvertrouwen bij het zoeken van werk'. De gebruikte vragen zijn: 'Ik heb een goed beeld van mijn sterke en zwakke kanten die belangrijk zijn bij het zoeken naar werk'; 'Het gebruiken van sociale contacten voor het vinden wan werk gaat mij makkelijk af'; 'Het zoeken en vinden van informatie over een bepaalde baan of organisatie gaat mij makkelijk af'; 'Ik vind het moeilijk om op mogelijke werkgevers indruk te maken met wat ik kan en wat ik weet'; 'Ik heb er vertrouwen in dat ik een goede indruk kan maken tijdens sollicitatiegesprekken'; 'Ik denk dat ik niet zo goed ben in het zoeken naar werk'; 'Ik heb er vertrouwen in dat ik een goede sollicitatiebrief kan schrijven'; 'Ik ben goed in staat mijn sociale contacten te gebruiken voor het zoeken naar ander werk'. De acht items werden gescoord met een vijfpunts-Likert-schaal met als schaalankers (I) 'helemaal oneens' tot (5) 'helemaal eens'. De schaal heeft op meetmoment I een betrouwbaarheid van .77 (Cronbach's alfa) en op meetmomenten 2 en 3 respectievelijk .80 en .78 .

\section{Werkstatus}

Werkstatus is in alle vragenlijsten gemeten. Er werd hierbij gevraagd in welke werk-, opleidings- of uitkeringssituatie iemand zich bevond. Deelnemers werden in dit onderzoek ingedeeld in de categorie 'een baan gevonden' indien zij aangaven een voltijd of deeltijd betaalde baan gevonden te hebben. 


\section{Resultaten}

\subsection{Zelfeffectiviteit getoetst}

Figuur I suggereert dat de mate van zelfeffectiviteit is gestegen na de training en ook na zes maanden nog steeds verhoogd is.

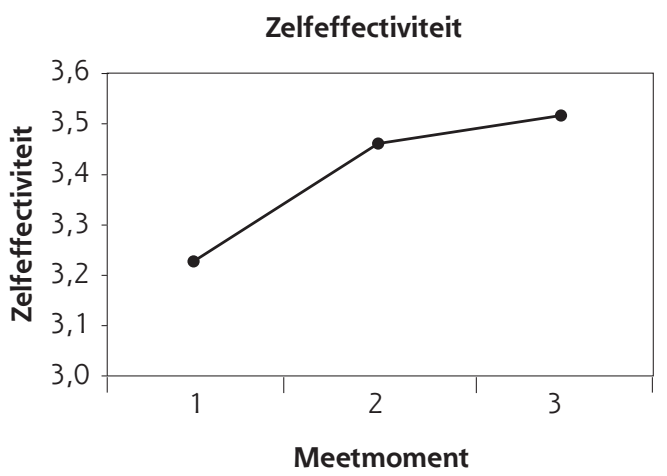

Figuur 1 Gemiddelde zelfeffectiviteit op de voormeting (meetmoment 1), één maand na de training (meetmoment 2 ) en zes maanden na de training (meetmoment 3); zelfeffectiviteit is gemeten op een vijfpuntsschaal (1-5)

Bovenstaande verschillen zijn getoetst door middel van een GLM herhaalde metingen met 'simple' contrast effecten. Er is een significant effect van tijd op waargenomen zelfeffectiviteit gevonden $(\mathrm{F}(\mathrm{I} .90,5 \mathrm{I} 7.02)=48.22, \mathrm{p}<.0 \mathrm{I}) .{ }^{1} \mathrm{Bij}$ de contrastanalyses bleek de zelfeffectiviteit na één maand $(\mathrm{M}=3.48, \mathrm{SD}=0.58)$ significant hoger te zijn dan op de voormeting $(\mathrm{M}=3.25, \mathrm{SD}=0.6 \mathrm{I})(\mathrm{F}(\mathrm{I}, 272)=73 . \mathrm{I} 3, \mathrm{p}<. \mathrm{oI})$. Ook na zes maanden $(\mathrm{M}=3.54, \mathrm{SD}=0.57)$ bleek de zelfeffectiviteit significant hoger te zijn dan op de voormeting $(\mathrm{F}(\mathrm{I}, 272)=80.29, \mathrm{p}<. \mathrm{OI})$. Na zes maanden is de zelfeffectiviteit zelfs significant hoger dan één maand na de training $(\mathrm{F}(\mathrm{I}, 272)=$ $4.04, \mathrm{p}<.05)$.

Exploratief is vervolgens nagegaan of er verschillen zijn in het effect van de training op zelfeffectiviteit tussen demografische groepen. Daarbij is gekeken naar geslacht, etnische achtergrond, opleidingsniveau, leeftijd en de duur van de werkloosheid. De variabele geslacht $(\mathrm{F} \text { (I.93,4IO.I8 }=4.27, \mathrm{p}<.05)^{2}$ bleek een interactie-effect te hebben met tijd op waargenomen zelfeffectiviteit (zie figuur 2). Bij het bekijken van de contrast effecten ('simple first') bleek de interactie zowel voor het contrast tussen meetmoment I en $2\left(\mathrm{~F}\left(\mathrm{I}, 2 \mathrm{I}_{3}=5.84, \mathrm{p}<.05\right)\right.$, als voor het contrast tussen meetmoment $\mathrm{I}$ en $3(\mathrm{~F}(\mathrm{I}, 2 \mathrm{I} 3)=6.2 \mathrm{O}, \mathrm{p}<.05)$ significant te zijn. De interactie bleek niet significant voor wat betreft het contrast tussen meetmoment 2 en $3(\mathrm{~F}(\mathrm{I}, 2 \mathrm{I} 3=0.2 \mathrm{I}, \mathrm{n} . \mathrm{s})$. Zoals figuur 2 laat zien, blijken vrouwen $(\mathrm{M}=3 . \mathrm{r} 3, \mathrm{SD}=0.60)$, in vergelijking met mannen $(M=3.37, S D=0.59)$, een lager niveau van zelfeffectiviteit te hebben op meetmoment I. Ook stijgen vrouwen meer tussen meetmoment I en $2 .{ }^{3}$ 


\section{Zelfeffectiviteit voor mannen en vrouwen}

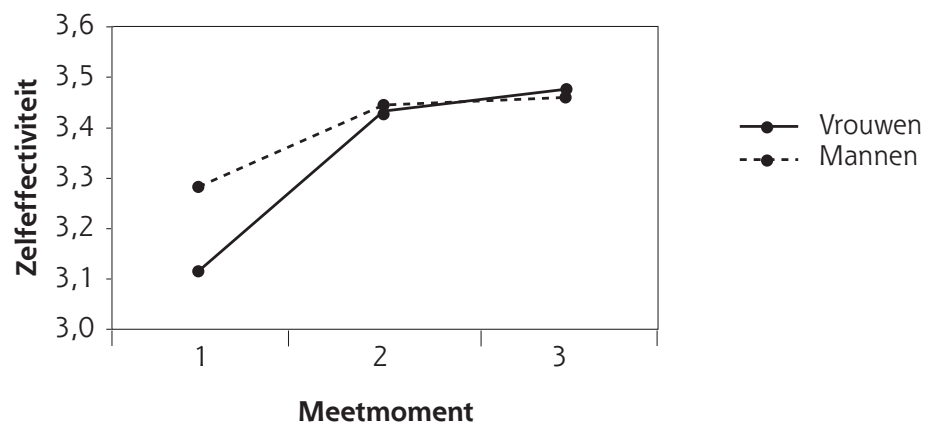

Figuur 2 Zelfeffectiviteit voor mannen en vrouwen op de voormeting (meetmoment 1), één maand na de training (meetmoment 2 ) en zes maanden na de training (meetmoment 3); zelfeffectiviteit is gemeten op een vijfpuntsschaal (1-5)

\subsection{Werkstatus}

Op meetmoment 2 gaven I2 respondenten (4\%) aan een baan te hebben. Op meetmoment 3 gaven 56 respondenten $(20 \%)$ aan een baan te hebben gevonden.

De vraag of een stijging in zelfeffectiviteit de kans op het vinden van werk vergroot, is met behulp van GLM herhaalde metingen onderzocht, met werkstatus als onafhankelijke variabele. Respondenten die aangeven op meetmoment 3 een baan te hebben gevonden $\left(\mathrm{M}_{\mathrm{t} 1}=3.39, \mathrm{SD}_{\mathrm{t} 1}=0.66 ; \mathrm{M}_{\mathrm{t} 2}=3.62, \mathrm{SD}_{\mathrm{t} 2}=0.63 ; \mathrm{M}_{\mathrm{t} 3}=3.73, \mathrm{SD}_{\mathrm{t} 3}\right.$ $=0.54$ ), laten gemiddeld genomen een hogere zelfeffectiviteit zien dan respondenten die geen baan hebben gevonden $\left(\mathrm{M}_{\mathrm{t} 1}=3.2 \mathrm{I}, \mathrm{SD}_{\mathrm{t} 1}=0.59 ; \mathrm{M}_{\mathrm{t} 2}=3.45, \mathrm{SD}_{\mathrm{t} 2}=0.57\right.$; $\left.\mathrm{M}_{\mathrm{t} 3}=3.50, \mathrm{SD}_{\mathrm{t} 3}=0.56\right)$. Dit verschil is statistisch significant $(\mathrm{F}(\mathrm{I}, 275)=4.68, \mathrm{p}<.05)$. Er bleek echter geen interactie te zijn tussen werkstatus en tijd $(F(I, 275)=0.03$, n.s. $)$. De zelfeffectiviteit van respondenten die wel een baan hadden gevonden, steeg dus niet meer dan bij respondenten die geen baan hadden gevonden. ${ }^{4}$

\subsection{Begeleiding na JOBS}

Exploratief is ook onderzocht in hoeverre de begeleiding na JOBS heeft bijgedragen aan de zelfeffectiviteit van deelnemers. Dit is getoetst middels een herhaaldemetingenanalyse, waarin het aantal consulten met de reïntegratieconsulent en het aantal consulten met iemand van de sociale dienst als covariaten waren opgenomen en het al dan niet ontvangen van overige begeleiding als (dichotome) onafhankelijke variabele. Deze analyse liet zien dat bovengenoemde variabelen geen significante hoofdeffecten of interactie-effecten met tijd hadden. De begeleiding na JOBS heeft dus geen invloed op de (stijging in) zelfeffectiviteit. 


\section{Discussie}

In dit onderzoek is een theoretische vergelijking gemaakt tussen de informatiebronnen, van zelfeffectiviteit (Bandura, I997) en de componenten van de JOBStraining, een training die erop gericht is (langdurig) werklozen te ondersteunen bij het zoeken van werk. Daarnaast is getoetst wat het effect van JOBS is op de waargenomen zelfeffectiviteit, voor zowel de korte als de lange termijn. Ook is exploratief onderzocht of er verschillen zijn tussen demografische groepen in de mate van zelfeffectiviteit, voor en na de JOBS-training. Ten slotte is nagegaan of een stijging in zelfeffectiviteit al dan niet samenhangt met het vinden van werk. Op deze wijze wordt inzicht geboden in het mechanisme waardoor de JOBS-training succesvol is in het activeren van (langdurig) werklozen.

\subsection{Theoretische vergelijking JOBS - bronnen zelfeffectiviteit}

108 Uit de theoretische vergelijking kwam naar voren dat de componenten van de JOBS-training (vaardigheidstraining, het actieve leerproces, anticiperen op belemmeringen en teleurstellingen, en sociale steun) op verschillende manieren aansluiten bij de vier bronnen van zelfeffectiviteit zoals geformuleerd door Bandura (I997) (uitvoerende ervaring, indirecte ervaring, verbale overreding en fysiologische en affectieve stimuli). De aansluiting is niet voor elke component echter even sterk. De vaardigheidstrainingen hebben duidelijk betrekking op zowel uitvoerende als indirecte ervaringen. Het actieve leerproces omvat, naast de vaardigheidsoefeningen, ook groepsdiscussie en de wijze waarop de trainers (impliciet) kennis aandragen. Deze aspecten zou men kunnen relateren aan indirecte ervaringen en verbale overreding, al dan niet impliciet. Het anticiperen op belemmeringen en teleurstellingen zou men kunnen relateren aan de fysiologische en affectieve toestand van deelnemers. Sociale steun, ten slotte, lijkt betrekking te hebben op verbale overreding.

\subsection{Effect JOBS op zelfeffectiviteit}

Op grond van eerder onderzoek (bijv. Blonk \& Brenninkmeijer, 2005; Van Ryn \& Vinokur, 1992) en de aansluiting van JOBS op de componenten van zelfeffectiviteit zoals geformuleerd door Bandura, werd verwacht dat JOBS zou leiden tot een stijging in de zelfeffectiviteit van deelnemers. Deelnemers blijken inderdaad één maand na de training hoger te scoren op zelfeffectiviteit dan voor de training. Bandura (1997) stelt dat een stijging in waargenomen zelfeffectiviteit die gegrond is op daadwerkelijke vaardigheden door praktijkervaring, verstevigd zal worden en niet zal dalen. Dit is bij de JOBS-deelnemers waar te nemen. Zes maanden later is hun zelfeffectiviteit nog steeds hoger dan voor de training en zelfs nog hoger dan één maand na de training. Het positieve effect van JOBS lijkt dus door te werken op de lange termijn.

\subsection{Verschillen tussen demografische groepen}

Middels exploratieve analyses is onderzocht of er verschillen zijn tussen demografische groepen in de mate waarin de zelfeffectiviteit stijgt. Hierbij is onder meer gekeken naar geslacht, etnische achtergrond, opleidingsniveau, leeftijd en de duur van de werkloosheid. Het bleek dat vrouwen voorafgaand aan de training een relatief lager niveau van zelfeffectiviteit hebben en de eerste maand sterker stijgen in 
hun zelfeffectiviteit dan mannen. Geconcludeerd kan worden dat vrouwen weliswaar sterker stijgen in hun zelfeffectiviteit, maar dat zowel vrouwen als mannen profiteren van de JOBS-training. De bevinding dat de overige demografische variabelen geen invloed hebben op de mate waarin mensen stijgen in hun zelfeffectiviteit geeft aan dat de training breed inzetbaar is voor verschillende demografische groepen.

\subsection{Relatie tussen zelfeffectiviteit en het vinden van werk}

Van alle respondenten vonden er 56 een baan (20\%), gemeten in de eerste zes maanden na de JOBS-training. Dit percentage is in overeenstemming met het percentage dat in onze eerdere studie is gevonden (Blonk \& Brenninkmeijer, 2005). In de eerdere studie vonden JOBS-deelnemers vaker een baan dan deelnemers in de controleconditie en deelnemers die een persoonsgebonden budget ontvingen. Hoewel het percentage mensen dat een baan vindt met JOBS relatief hoog is, betekent het wel dat de meerderheid van deelnemers geen baan vindt. Voor deze mensen is het derhalve van groot belang dat zij aanvullende ondersteuning krijgen bij het zoeken van werk.

Zowel de respondenten die een baan hebben gevonden als de respondenten die geen baan hebben gevonden, laten een duidelijke stijging in hun zelfeffectiviteit zien. Deze groepen verschillen niet in de mate waarin hun zelfeffectiviteit stijgt. De respondenten die een baan hebben gevonden, hebben gemiddeld genomen wel een hoger niveau van waargenomen zelfeffectiviteit, voor en na de training. Blijkbaar is niet zozeer een stijging van waargenomen zelfeffectiviteit belangrijk om een baan te vinden, maar gaat het om het absolute niveau van zelfeffectiviteit. Dit zou betekenen dat er wellicht een minimumniveau nodig is om te kunnen slagen.

\subsection{Begeleiding na JOBS}

Exploratief is ook nagegaan of de begeleiding die mensen na JOBS ontvingen gerelateerd was aan (veranderingen in) waargenomen zelfeffectiviteit. De begeleiding die de deelnemers noemen betreft veelal één tot vier gesprekken met de consulent van het reïntegratiebedrijf, maar er worden ook andere vormen van begeleiding genoemd, zoals sollicitatietrainingen. De begeleiding na JOBS bleek niet van invloed op de zelfeffectiviteit. Hierbij dient te worden opgemerkt dat slechts zeer beperkt informatie aanwezig was over de begeleiding die mensen na JOBS hadden ontvangen. $Z_{\mathrm{o}}$ is bijvoorbeeld niet bekend in hoeverre deze begeleiding ook volgens de JOBS-methodiek werd gegeven. Voor een effectieve individuele nazorg lijkt het van groot belang dat de methodiek van JOBS zo veel mogelijk gehandhaafd blijft. Dat betekent bijvoorbeeld dat consulenten positief gedrag bekrachtigen, veel aandacht besteden aan het anticiperen op en omgaan met belemmeringen, en de kennis en ervaringen van de cliënt centraal stellen. De manier waarop de begeleiding na JOBS is opgezet en zich richt op het versterken van de zelfeffectiviteit, zal mede bepalen hoe de zelfeffectiviteit van mensen zich op de lange termijn ontwikkelt.

\subsection{Suggesties voor vervolgonderzoek}

Hoewel zelfeffectiviteit een belangrijke variabele blijkt te zijn waarop de JOBS-training ingrijpt, is het niet de enige variabele die centraal staat in de methodiek van de 
JOBS-training. Een andere belangrijke variabele in deze methodiek is het omgaan met en het voorbereiden op belemmeringen en tegenslagen. Vervolgonderzoek zou zich kunnen richten op de vraag in hoeverre deze variabele gerelateerd is aan het vinden van werk na de JOBS-training. Op deze wijze wordt meer inzicht gegeven in de aangrijpingspunten voor het vergroten van de kans op een baan voor (langdurig) werklozen.

\subsection{JOBS en de praktijk}

Zelfeffectiviteit is een belangrijke factor voor het vinden van werk. In de begeleiding van werklozen is het dus van groot belang de zelfeffectiviteit van de deelnemers te versterken. De JOBS-training is een instrument dat hierop aangrijpt. JOBS heeft een stimulerende invloed op de zelfeffectiviteit, in het bijzonder bij vrouwen. Ook in de individuele nazorg van cliënten is het belangrijk aan de zelfeffectiviteit te blijven werken. Met name werklozen die wel zijn gestegen in zelfeffectiviteit maar nog extra stimulering kunnen gebruiken, zullen hier waarschijnlijk baat bij hebben. De resultaten laten zien dat JOBS in ieder geval een goed begin maakt.

\section{Noten}

1 Bij de toetsing van verschillen over tijd mocht sfericiteit niet worden aangenomen en is aantal vrijheidsgraden gecorrigeerd met behulp van Greenhouse-Geisser.

2 Zie noot 1 .

3 Additionele analyses laat zien dat mannen, net als vrouwen, wel significant stijgen in hun zelfeffectiviteit $(\mathrm{F}(2,142)=0.17, \mathrm{p}<.01$ resp. $\mathrm{F}(2,155)=0.32, \mathrm{p}<.01)$.

4 Deze analyse is herhaald met correctie voor demografische variabelen (geslacht, etnische achtergrond, opleidingsniveau, leeftijd en duur van de werkloosheid). Ook uit deze analyse kwam geen significante interactie tussen werkstatus en tijd naar voren $(\mathrm{F}(2,244)=0.17$, n.s. $)$.

\section{Literatuur}

Ajzen, I. (1991). The theory of planned behavior. Organizational behaviour and human decision processes, 50, I79-2II.

Bandura, A. (1977a). Self-efficacy: Toward a unifying theory of behavioral change. Psychological Review, 84, I9I-215.

Bandura, A. (1977b). Social Learning Theory. Englewood Cliffs, NJ: Prentice Hall.

Bandura, A. (1986). Social foundations of thought and action: a social cognitive theory $\left(2^{\mathrm{e}} \mathrm{druk}\right)$. New York: Prentice Hall.

Bandura, A. (1997). Self-efficacy: the exercise of control ( $7^{\mathrm{e}}$ druk). New York: W.H. Freeman and Company.

Blonk, R.W.B. \& Versteeg, A.M. (2002). Motivatie en werkzoekgedrag bij uitkeringsgerechtigden. Hoofddorp: TNO Arbeid.

Blonk, R.W.B. \& Brenninkmeijer, V. (2005). Experimenteren in activering. In E. de Vos, J. van Genabeek (Eds.), Verraderlijk effectief: Prestatiemeting van reïntegratie en activering deel 2 (pp. I4I-I63). Amsterdam: PlantijnCasparie.

Caplan, R.D., Vinokur, A.D. \& Price, R.H. (I997). From job loss to reemployment: field experiments in prevention-focused coping. In G.W. Albee \& T.P. Gullotta (Eds.) Primary Preventions Works, (pp. 34I-379). Thousand Oaks, CA: Sage.

Caplan, R.D., Vinokur, A.D., Price, R.H. \& Van Ryn, M. (1989). Job seeking, reemployment, and mental health: A randomised field experiment in coping with job loss. Journal of Applied Psychology, 74, 759-769. 
Catalano, R. (199I). The health effects of economic insecurity. American Journal of Public Health, 8I, II48-II52.

Centraal Bureau voor de Statistiek (2005). Werkloosheid stabiel, Persbericht, donderdag 20 oktober 2005 9:30. Http://www.cbs.nl/nl-NL/menu/themas/arbeid-inkomen-socialezekerheid/arbeidsmarkt/publicaties/persberichten.

Dooley, D. \& Catalano, R. (1980). Economic change as a cause of behavioral disorder. Psychological Bulletin, 87, 450-468.

Eden, D. \& Aviram, A. (1993). Self-efficacy training to speed reemployment: Helping people to help themselves. Journal of Applied Psychology, 78, 353-360.

Ellis, R.A. \& Taylor, M.S. (1983). Role of self-esteem within the job search process. Journal of Applied Psychology, 68, 632-640.

Janis, I.L. \& Mann, L. (1977). Decision making: a psychological analysis of conflict, choice and commitment. New York: The Free Press.

Kessler, R.C., Turner, J.B. \& House, J.S. (I988). The effects of unemployment on health in a community survey: Main, modifying, and mediating effects. Journal of Social Issues, 44, $69-85$.

McKee-Ryan, F.M., Song, Z., Wanberg, C.R. \& Kinicki, A.J. (2005). Psychological and physical well-being during unemployment: A meta-analytic study. Journal of Applied Psychology, 90, 53-76.

Meichenbaum, D. (1985). Stress Inoculation Training. New York: Pergamon Press.

Price, H., Van Ryn, M. \& Vinokur, A.D. (1992). Impact of a preventive job search intervention on the likelihood of depression among the unemployed. Journal of Health and Social Behavior, 33, 158-167.

Taris, T.W., Heesink, J.A.M. \& Feij, J.A. (1995).The evaluation of unemployment and job searching behavior: A longitudinal study. Journal of Psychology, I29, 30I-3I4.

Van Hooft, E.A.J., Born, M.Ph., Taris, T.W., Van der Flier, H. \& Blonk, R.W.B. (2004). Predictors of job search behavior among employed and unemployed people. Personnel Psychology, 57, 25-59.

Van Ryn, M., \& Vinokur, A.D. (1992). How did it work? An examination of the mechanisms through which an intervention for the unemployed promoted job-search behavior. American Journal of Community Psychology, 20, 577-597.

Vinokur, A.D., Caplan, R.D. \& Williams, C.C. (I987). Effects of recent and past stress on mental health: Coping with unemployment among Vietnam veterans and nonveterans. Journal of Applied Psychology, i7, 708-728.

Vinokur, A.D., Van Ryn, M., Gramlich, E.M. \& Price, R.H. (I99r). Long-term follow-up and benefit-cost analysis of the jobs program: a preventive intervention for the unemployed. Journal of Applied Psychology, 76, 213-219.

Vuori, J., Silvonen, J., Vinokur, A.D. \& Price, R.H. (2002). The työhön job search program in Finland: Benefits for the unemployed with risk of depression or discouragement. Journal of occupational health psychology, 7, 5-19.

Wanberg, C.R., Glomb, T.M., Song, Z. \& Sorenson, S. (2003). Job-search persistence during unemployment: A ten wave longitudinal study. Manuscript submitted for publication.

Wanberg, C.R., Watt, J.D. \& Rumsey, D.J. (I996). Individuals without jobs: empirical study of job-seeking behavior and re-employment. Journal of Applied Psychology, 81, 76-87.

\section{Self-efficacy: the Effect of JOBS, a Group Intervention for the Unemployed}

Veerle Brenninkmeijer, Arjan Van Houwelingen, Roland Blonk \& Nico Van Yperen, Gedrag \& Organisatie, Volume 19, Juni 2006, nr. 2, pp. 97

This study is about the JOBS training, a group training for the unemployed (Vinokur, Van Ryn, Gramlich \& Price, 1991) by increasing individuals' self-efficacy. First, a theoretical comparison was made between Bandura's (1977a) four sources of self-efficacy and the components of the JOBS training. Subsequently, we tested the effect of JOBS on self-efficacy in a longitudinal study among 281 JOBS parti- 
cipants. JOBS indeed increased the self-efficacy at both the short and long term (after one and six months). The increase on the short term was stronger among women. The increase in self-efficacy was not related to the actual job finding, but the absolute level of self-efficacy was.

Key words: JOBS training, self-efficacy, unemployment 